\title{
LEGAL AND VICTIMOLOGICAL PERSPECTIVE ON SEXUAL VIOLENCE AGAINST CHILDREN CASES IN INDONESIA
}

\author{
Raden Muhammad Arvy Ilyasa* \\ Faculty of Law, Universitas Negeri Semarang, Indonesia \\ *Email: radenmuhamamd@gmail.com
}

\begin{abstract}
Every year in Indonesia there are various cases of sexual violence against children whose quantity is increasing every year. Protection of children from all threats of crime that can threaten their survival is contained in the constitution of the State of Indonesia as a country that upholds law and human rights. When children experience incidents of sexual violence, their future will be threatened due to psychological, mental and social trauma factors. Therefore, in this paper, the author wants to examine how to handle cases of sexual violence in Indonesia from a legal and victimological perspective by identifying the problem, namely how is legal protection for children as victims in cases of sexual violence and how is the perspective of victimology in this case the study of victims in acts of violence. crime or crime.
\end{abstract}

Keywords: Sexual Violence; Victimology; Child Protection

The Indonesian Journal of International Clinical Legal Education DOI: https://doi.org/10.15294/ijicle.v3i3.48269

Submitted: Feb 22, 2021 Revised: April 25, 2021 Accepted: August 9, 2021 Available online at https://journal.unnes.ac.id/sju/index.php/iccle (C) 2021 Authors. This work is licensed under a Creative Commons AttributionShareAlike 4.0 International License (CC BY-SA 4.0). All writings published in this journal are personal views of the authors and do not represent the views of this journal and the author's affiliated institutions. 


\section{INTRODUCTION}

Children are an inseparable part of the survival of a human being and the sustainability of a nation and state. In the Indonesian constitution, children have a strategic role and it is expressly stated that the State guarantees the rights of every child to survival, growth and development as well as protection from violence and discrimination. Therefore, the best interests of children should be lived as the best interests for the survival of mankind. ${ }^{1}$

The development of progress in society that is so rapid, of course has consequences in social life. This has an impact on the tendency of community members themselves to be able to interact with one another. In this interaction relationship, there are often acts that violate the provisions of the law or the rules that have been determined by the community itself. To be able to create a sense of security, peace and order in society. One example of this deviant act is sexual violence. The sexual violence discussed in this article is that which occurs in children. Child Sexual Abuse involves persuading or coercing a child to take part in sexual activities, or encouraging a child to behave in an inappropriate sexual context including completing or attempting sexual acts or contact or non-contractual sexual interactions with a child by adults. ${ }^{2}$ There are several reasons why children are often the targets of sexual violence, namely:

1. Children are always in a weaker and helpless position

2. Morality in society, especially in this case, is that the perpetrators of sexual violence are low

3. Control and awareness of parents in anticipating crimes against children is still low. ${ }^{3}$

According to the World Health Organization, namely WHO, sexual violence against children is a form of abuse or mistreatment of children in the form of physical, emotional, sexual harm, neglect of care and exploitation for commercial purposes that may or may not endanger their health, survival, dignity or development. , acts of violence are obtained from people who are responsible, trusted or in power in the protection of the child. ${ }^{4}$

1 Angger Sigit Pramukti dan Fuady Primaharsya, "Sistem Peradilan Pidana Anak", Yogyakarta: Pustaka Yusitisia, 2015, p. 1.

2 Molyneux, dkk, "Sexual abuse of children in low-income settings: time for action", Paediatrics and International Child Health, Volume 33, Issue 4, p. 239.

3 Disemy Humaria B, dkk, "Kekerasan Seksual Pada Anak: Telaah Relasi Pelaku Korban dan Kerentanan Pada Anak", Jurnal Psikoislamika, Volume 12, Issue 2, 2015, p. 5.

$4 \quad$ Ibid, p. 6. 
Criminal behavior in terms of sexual violence has a fairly high quantity level every year in Indonesia, and it is not even uncommon that the victims in this crime are children who are still under age. The Witness and Victim Protection Agency (LPSK) noted an increase in requests for protection from sexual violence against children. In fact, this number exceeds other criminal cases. LPSK noted that there has been an increase in cases of sexual violence against children that have occurred since 2016 which was 25 cases, then increased in 2017 to 81 cases, and peaked in 2018 to 206 cases. In addition, according to the Deputy Chairperson of LPSK Achmadi, there was also an increase in requests for protection and legal assistance for crimes of sexual violence against children. According to him, in 2016, there were 35 victims, then in 2017 there were 70 victims, and as many as 149 victims in 2018. Then Achmadi also revealed that perpetrators of sexual violence against children were dominated by the closest people, with a percentage of 80.23 percent. Meanwhile, according to him, 19.77 percent were carried out by unknown people. Meanwhile, the son-in-law of another LPSK Deputy Chair, Antonius PS Wibowo, added that the number of requests for victims of sexual violence against children exceeded other crimes. According to him, this phenomenon illustrates the emergency in Indonesia of sexual violence against children. ${ }^{5}$

Even in educational institutions themselves, which are one of the most popular places for children, there are cases of sexual violence against children. Launching data from the Indonesian Child Protection Commission (KPAI) regarding data on the level of sexual violence against children in the period 2019, it was noted that there were 21 cases of sexual violence with the number of victims reaching 123 children that occurred in educational institutions. The data consists of 123 victims with details of 71 girls and 52 boys. According to the KPAI Commissioner for Education, Retno Listyarti, both boys and girls are vulnerable to being victims of sexual violence in schools. This KPAI data shows that the perpetrators can deceive many victims based on 21 perpetrators of violence with the victims reaching 123 children. The 21 perpetrators consisted of 20 male and 1 female perpetrator. The majority actors consist of teachers as much as 90 percent and school principals as much as 10 percent. The results of the KPAI supervision show that of the 21 cases of sexual assault that occurred in the school, 13 cases or 62 percent occurred at the elementary school level, 5 cases or 24 percent at the junior high school level/equivalent and 3 cases or 14 percent at the high school level. ${ }^{6}$

5 Matius Alfons, "LPSK: Kasus Kekerasan Seksual pada Anak Meningkat Tiap Tahun”, https://news.detik.com/berita/d-4637744/lpsk-kasus-kekerasan-seksualpada-anak-meningkat-tiap-tahun, accessed on 24 June 2020.

6 Wisnoe Moerti, "Data KPAI, Selama 2019 Ada 123 Anak Korban Kekerasan Seksual di Institusi Pendidikan", https://www.merdeka.com/peristiwa/data-kpai- 
Children are social beings just like adults. A child needs other people to be able to help develop his abilities, because children are born with all the weaknesses so that without the help of other people a child cannot reach a normal level of humanity. Children are not the same as adults, children have a tendency to deviate from law and order caused by limited knowledge and understanding of the realities of life. Children learn more easily by the examples they receive from emergent and coercive rules. ${ }^{7}$ Children are also as shoots, potentials and young generations who carry out the ideals of the nation, have a strategic role and have special characteristics and characteristics that ensure the continuity of the existence of the nation and state in the future. Protection against all acts of crime that can threaten their survival is certainly a special concern for the government as the incumbent. Protection of children in a society, nation, or state is a benchmark of human civilization, so to seek protection for children in this case in cases of sexual violence is a shared obligation to be able to seek child protection for the sake of the future interests of the nation and the state, because children in the law -Law Number 23 of 2002 is the bud, potential, and successor of the nation's ideals.

This research uses normative juridical law research methods. To obtain data in this legal research, the author uses several approaches, namely the statute approach, the case approach, and also the comparative approach. This study uses literature research by obtaining secondary data in the form of literature books, research results, journals, articles, and legal regulations related to the object of research, namely infrastructure development, human rights, and customary law communities. ${ }^{8}$

\section{THE PROBLEMS OF SEXUAL VIOLENCE IN CHILDREN: LEGAL AND PRACTICAL ANALYSIS}

The definition of sexuality according to the APNET Conference (Asia Pacific Network for Social Health) in Cebu, Philippines 1996 says that sexuality is a person's sexual expression that is considered socially

selama-2019-ada-123-anak-korban-kekerasan-seksual-di-institusi-

pendidikan.html\#: :text=Kontak\%20Kebijakan\%20Privasi-

,Data\%20KPAI\%2C\%20Selama\%202019\%20Ada\%20123\%20Anak,Kekerasan\%

20Seksual\%20di\%20Institusi \%20Pendidikan\&text=Merdeka.com\%20\%2D\%20K omisi $\% 20$ Perlindungan $\% 20$ Anak,yang\%20terjadi $\% 20$ di $\% 20$ institusi $\% 20$ pendidik an., accessed on 24 June 2020.

7 Ario Ponco Wiguno, "Kajian Viktimologi Terhadap Anak Sebagai Korban Tindak Pidana Kesusilaan”, Jurnal Ilmu Hukum Legal Opinion, Volume 1, Issue 1, 2013, pp. 2.

8 Peter Mahmud Marzuki, “Penelitian Hukum”, Jakarta: Media Group, 2005, pp. 2025. 
acceptable and contains broad and deep aspects of personality. Sexuality is a combined form of a person's feelings and behavior which is not only based on biological sex characteristics, but also as an inseparable aspect of human life. Today, it is undeniable that information about sex issues is actually very open and easy to access. In connection with the act of prostitution as a form of crime that can be criminalized, criminal liability is defined as the obligation to be able to pay the retribution that will be received by the perpetrator from someone who has been harmed. This form of accountability is not only in terms of legal issues, but also issues of moral values or decency that exist in a society. ${ }^{9}$

Sexual crimes are all forms of social action, attempted sexual acts, unwanted comments, sex trafficking, using coercion, threats, physical coercion by anyone regardless of the relationship with the victim in any situation, including but not limited to home and work. Sexual crimes take many forms including rape, sex slavery and/or sex trafficking, forced pregnancy, sexual violence, sexual exploitation and/or sex abuse and abortion. ${ }^{10}$

Meanwhile, the term used in the Criminal Code (KUHP) is a crime against decency, not using the term sexual violence (sexual violence is defined as a form of criminal act related to sexuality that can be committed against men or women. The use of the term from decency This causes the public, especially law enforcement officers, to be trapped in the placement of articles of morality only as a matter of violation of cultural values, religious norms, or manners related to sexual desire (lust), not crimes against one's body and soul.

\section{Types of Sexual / Moral Crimes According to the Criminal Code}

Crimes in the field of decency are crimes related to sexual matters. In the Criminal Code (KUHP) it is regulated in Chapter XV1 Book II with the title "Crime Against Morality".

a) Crimes by violating public decency (Article 281)

b) Crime of pornography (Article 282)

c) Crimes of pornography against minors (Article 283)

d) Crime of pornography in carrying out their livelihood (Article 283 bis)

e) The crime of adultery (Article 284)

f) The crime of rape for sexual intercourse (Article 2850

g) The crime of having sex with a woman out of wedlock who is unconscious or helpless (Article 286)

9 Oksidelfa Yanto, "Prostitusi Online Sebagai Kejahatan Kemanusiaan Terhadap Anak: Telaah Hukum Islam dan Hukum Positif”, Jurnal Ahkam, Volume 16, Issue 2, 2016, p. 90.

10 Dadang Hawari, "Psikopatologi Kejahatan Seksual”, Depok: Badan Penerbit Fakultas Kedokteran Universitas Indonesia, 2011, p. 3 


\section{Raden Muhammad Arvy Ilyasa}

h) The crime of having sex with a woman out of wedlock who is not yet 15 years old (Article 287)

i) The crime of having sex with a woman in a marriage that is not yet due and causing injury (Article 288)

j) The crime of rape is obscene or acts that attack the honor of morality (Article 289)

k) The crime of obscene acts on people who have fainted, on people who are not yet 15 years old or have not been married (Article 290)

1) The crime of same-sex obscenity, to a person who is not yet an adult (Article 292)

$\mathrm{m})$ The crime of moving people to commit obscene acts with minors (article 293)

n) The crime of committing obscene acts with their children, children under their supervision and others who are not yet mature (Article 294).

o) The crime of youth committing obscene acts for his child, stepson and others who are not yet an adult (article 295)

p) The crime of making obscene acts as a livelihood or habit (article 296)

q) The crime of trafficking in women and boys who are not yet adults (Article 297)

r) The crime of treating a woman with the hope that her pregnancy can be aborted (Article 299).

\section{Definition of Child and Child Age Limit}

In general, what is meant by a child is a descendant or the next generation of a relationship between a man and a woman both in marriage and out of wedlock. In the perspective of Customary Law as explained by Soerojo Wignjodipoero: "Unless the parents see it as the next generation, the child is also seen as a place where all the hopes of his parents in the future must be shed, and he is also seen as a protector of his parents when the parents are no longer physically able to earn a living". ${ }^{11}$

Some of the meanings of children according to the laws and regulations in force in Indonesia are:

a. Civil Code (KUHPerdata), Article 30 paragraph (1)

Mention that minors are those who have not reached the age of 21 (twenty one) years and have not been married before.

b. Law Number 39 of 1999 concerning Human Rights

A child is every human being who is under 18 (eighteen) years of age and unmarried, including a child who is still in the womb if this is in his interest.

11 Endang Sumiarni dan Chandera Halim, "Perlindungan Hukum Terhadap Anak Dalam Hukum Keluarga”, Yogyakarta: Universitas Atma Jaya, 2009, p. 10. 
c. Law Number 11 of 2011 concerning the Juvenile Justice System Explain that children who are 12 (twelve) years old and not yet 18 (eighteen) years old

d. Law Number 35 of 2014 concerning Amendments to Law Number 23 of 200 concerning Child Protection

A child is someone who is not yet 8 (eighteen) years old, including a child who is still in the womb

\section{The Factors of Sexual Violence Against Children}

The form of violence against children that occurs around us and as long as it is not only carried out by the child's family environment, but also occurs in the family environment. According to data, the perpetrators of child abuse are carried out by 68 percent by people known to the child, including 34 percent by their own biological parents. The report also states that girls in the current situation are very vulnerable to sexual violence. In general, the reasons for the perpetrators are very diverse. Meanwhile, the average victims ranged from 2-15 years, and some of them were reported to be 1 year and 3 months old. The perpetrators before and after committing sexual violence generally commit violence, and/or threats of violence, trickery and a series of lies. ${ }^{12}$

Cases of sexual violence as a crime of decency can be caused by various factors. This crime is quite complex and the causes are not independent. The cause can be influenced by supportive conditions, the presence of the victim who can indirectly encourage the perpetrator and it could be because of other elements that can influence it. In explaining the factors that can lead to this crime, many scholars have explained according to their respective fields of expertise. Criminology experts have tried to be able to formulate what are the factors that cause crime, but no one can give absolute limits regarding the main factors for the emergence of criminal acts. If you look for the cause of a crime, you will find various factors in it. Where in a certain factor that can lead to crime, while other factors lead to other types of crime as well. This is what some scholars call multiple factors. ${ }^{13}$ The cause of this crime is very complex, and within this complex factor, one factor influences the other. Edwin $\mathrm{H}$. Sutherland says that: "Crime is the result of various and varied factors, from that the current and future factors cannot be arranged according to a generally accepted provision without exceptions or in other words to explain criminal behavior there is no scientific theory". ${ }^{14}$

The main implementing actors in terms of the occurrence of rape as a form of sexual violence against children are influenced by various

12 Lukam Hakim Nainggolan, "Bentuk-Bentuk Kekerasan Seksual Terhadap Anak di Bawah Umur", Jurnal Equality, Volme 13, Issue 1, 2008, pp. 73.

13 Ibid, p. 75.

14 Edwind H. Sutherland dan Donald R. Cressey, “Azas-Azas Kriminologi: Principle of Criminology”, Bandung: Alumni, 1977, p. 28. 
other factors that are outside of the perpetrator. But in general it can be said that the factors of crime are divided into two parts, namely internal factors and external factors. ${ }^{15}$

\section{a. Internal Factors}

Internal factors are factors that occur in each individual. This factor specifically looks at the individual and looks for things that have a relationship with the crime of rape. This can be seen from psychological factors, namely mental conditions or an abnormal self-state of a person can also encourage someone to commit a crime. In such circumstances, it is often found in human actions that there are unnoticed mistakes. If there are actions that are not aware of appearing, it can lead to acts that are deviant or tend to commit crimes. Since infancy humans have had a sex drive. This urge is the basis in the individual which is automatically formed because of the sex hormone substances contained in every human being. This sexual urge is very strong, and this urge demands to always be fulfilled. If we cannot control it, then the result will be a loss of balance which will affect the behavior of each of us in the activities of our daily lives. At a later stage if the need for sex is not channeled normally, there will be potential deviations such as rape. ${ }^{16}$ In fact, morality is not something that cannot be changed, but there are ups and downs, both individually and in society. The incidence of rape cases is caused by the very low moral effect of the perpetrators. Of these cases, many of them occurred, the victim was not a stranger to him even within the scope of his own siblings and children. The case provides the fact that the perpetrators are immoral people so that they can commit these acts.

\section{b. External Factors}

External factors are all kinds of factors that are outside the perpetrator. This can be seen from socio-cultural factors; the increasing cases of decency crimes or rape are closely related to socio-cultural aspects. Because the socio-cultural aspects that develop in this society greatly affect the ups and downs of a person's morality. It is a fact that with the rapid progress of science and technology, it is unavoidable to have a negative impact. Sociocultural aspects that develop during society can affect the highs and lows of morality. The second factor is the economy. Economic factors can also be one reason a person commits a crime of decency. Difficult economic conditions will bring people to low education and at a later stage have an impact on whether or not the work is good. This situation can cause a person to lose confidence and lead to

15 Hari Saherodji, "Pokok-Pokok Kriminologi”, Jakarta: Aksara Baru, 1980, pp. 3845 .

16 Kartini Kartono, "Psychologi Wanita, gadis remaja, dan Wanita Dewasa", Bandung: Alumni, p. 41. 
apathy, frustration, and loss of respect for the norms around him. The state of the economy as a factor that will directly or indirectly affect the main points of people's lives. This situation also affects the way a person lives. The third is the mass media factor. Mass media is a form of information advice in social life. Like newspapers, magazines, television and so on, it is a control tool that plays an important role in people's lives. This newspaper contains news information in such a way about events or events that occur in everyday life. However, it is possible that the news coverage of this newspaper was a factor in the incidence of crime. ${ }^{17}$

\section{LAW ENFORCEMENT AGAINST CHILD SEXUAL VIOLENCE CASES}

As in the provisions of Article 34 of the 1945 Constitution that the State in this case has the obligation to protect the dignity of the child. This provision has implications for the obligation of the State to be able to provide maximum protection for children. In Article 1 paragraph (1) of Law Number 23 of 2002, a child is a person who is not yet 18 years old, including a child who is still in the womb. This struggle in terms of child protection must be able to give birth to good law enforcement and create policies in laws and regulations that want the best interests of children for their future survival. In the case of child protection in Indonesia, which is increasingly complex and over time the cases have increased in terms of quality and quantity involving children, parents, and administrators, which have not been fully handled institutionally. ${ }^{18}$ In this case there should be an effective principle for the protection of child victims of sexual violence. This principle includes an element of improving the socio-economic-psychological conditions of the victims and the community and improving policies or institutions that cause violence and human rights violations in children. ${ }^{19}$ Children have a strategic role that cannot be separated from human survival and the sustainability of a nation and state. The state expressly states that it guarantees the right of every child to survival, growth and development as well as to protection from all forms of violence and discrimination. ${ }^{20}$

The development of human rights and the protection of children against them as proclaimed by the 1993 Vienna Declaration and the 2000

17 Lukam Hakim Nainggolan, Op. Cit.,p. 78.

18 Komisi Perlindungan Anak Indonesia, "Pedoman Pembentukan Komisi Perlindungan Anak Daerah (KPAD), Jakarta: KPAI, 2014, p. 11.

19 Kontras, "Keadilan Macet, Kekerasan Jalan Terus: Laporan Tahunan Kondisi HAM di Indonesia”, Jakarta: Kontras, 2013, p. 5.

20 Maruklak Pardede, "Aspek Hukum Kebijakan Penyuluhan Hukum Dalam Rangka Pelaksanaan Sistem Peradilan Anak, De Jure, 2017, Volume 17, Issue 17,p. 17. 


\section{Raden Muhammad Arvy Ilyasa}

Millennium Declaration must be able to create a culture of human rights approach. Human rights culture can be born starting with mutual respect for life and the rights associated with it. Basic rights that should not be violated include the right to life, self-development, recognition before the law, non-discrimination, privacy, property rights, religious freedom, security, family, peace, and so on. aware and ready to be able to develop it and appreciate it. ${ }^{21}$ There is an agreement that has emerged from various countries that the issue of children is organized in a forum called UNICEF (United International Children Educational of Fund). In Indonesia, children are classified as a vulnerable group apart from the elderly, the poor, pregnant women and people with disabilities. This is in line with Law Number 39 of 1999 Article 5 paragraph (3).

Protection for children is all kinds of activities to be able to guarantee and protect children and their rights so that they can live, grow, develop and participate optimally in accordance with human dignity and get adequate protection from all forms of violence and discrimination for the realization of children in Indonesia. quality, noble, and prosperous. ${ }^{22}$ Referring to Article 3 of Law Number 23 of 2002 in conjunction with Law Number 35 of 2014 contains important aspects, namely:

a) Guaranteed and fulfilled children's rights

b) Fulfillment of human dignity

c) Protection of children from violence and discrimination

d) The realization of quality children

e) Be noble

f) Prosperous

In Article 59 of Law Number 23 of 2002 in conjunction with Law Number 35 of 2014 it is explained that the government and other state institutions are obliged and responsible to provide special protection, namely:

a) Children in emergency situations

b) Children in conflict with the law

c) Children from minority and isolated groups

d) Children are exploited economically and or sexually

e) Trafficked children

f) Children who are victims of drug abuse

g) Child victims of abduction, sale and trafficking

h) Children who are victims of violence, both physically and or mentally, children with disabilities

21 Martinus Sardi, "Membangun Budaya Hak-Hak Asasi Manusia”, Media Hukum, Volume 23, Issue 1, 2016, p. 124.

22 I Gede Arya B. WInarta, dalam (Ed. Muladi, Hak Asasi (Anak) dalam Realitas Quo Vadis? dalam kumpulan naskah Hak Asasi Manusia (hakekat, Konsep dan Implikasinya dalam perspektif Hukum dan Masyarakat), Bandung: Refika Aditama, 2005, p. 227. 
i) Child victims of abuse and neglect. ${ }^{23}$

Special protection for children who are victims of criminal acts in accordance with Article 64 paragraph (3), namely there is a rehabilitation effort from both domestic and foreign institutions, efforts to protect from identity reporting through mass media and all forms of labeling, providing safety guarantees for victim witnesses and Expert witnesses, both physically, mentally and socially, provide accessibility to obtain information regarding the progress of the case. In Law Number 31 of 2014 concerning Amendments to Law Number 13 of 2006 concerning Protection of Witnesses and Victims, it has regulated what rights are owned by victims. These rights include:

a) Get protection for the personal security of family and property, and be free from threats related to the testimony that will be, is being or has been given

b) Participate in the process of selecting and determining the form of protection and security;

c) Provide information without pressure

d) Got a translator

e) Free from entangled questions

f) Get information about the progress of the case and court decisions

g) Knowing if the convict is released

h) Get a new identity and place of residence

i) Get reimbursed for transportation costs

j) Get legal advice and get temporary living expenses until the protection limit ends

k) Entitlement to medical assistance and psychosocial rehabilitation

1) Right to compensation

m) The right to restitution or compensation which is the responsibility of the perpetrator of the crime.

Law enforcement on the protection of children who experience sexual violence must be firm. Cases of sexual exploitation of children have even become the attention of the international community. Data shows that in Southeast Asia alone, the victims of child sexual exploitation have reached 2 million people. Meanwhile in Indonesia, from reports received in cases of children being victims of sexual exploitation, it reaches 700,000 people. With the presence of Law Number 13 of 2006 concerning the Protection of Witnesses and Victims as has been perfected in Law Number 31 of 2014 confirms that the presence of the State for victims of crime includes the provision of protection and assistance in the form of rehabilitation for victims, including in the case of child victims of exploitation. sexual. The service in question is in the form of psychological and psychosocial medical assistance. In addition, this Law also allows victims of crimes to be able

23 Bambang Waluyo, "Viktimologi Perlindungan Korban dan Saksi”, Jakarta: Sinar Grafika, 2012, pp. 70-72. 
to apply for compensation to the perpetrators or in the judicial process known as restitution. What is even more important is to be able to provide facilities for victims to get psychosocial rehabilitation. ${ }^{24}$

Various cases that appear and often occur to children throughout Indonesia, with explicit and repeated reporting. The other side of cases of violence against children is to remind the importance of maintaining the confidentiality of victims from media coverage. Moreover, regarding the interests of victims, it is also included in the form of completing the handling of cases with law enforcement processes. Victim justice can be fulfilled if the perpetrators are punished and the victim can undergo a non-traumatic process. The main problem in law enforcement in the context of handling cases of sexual violence has not been fully explained properly in the existing positive law. Taking lessons from poor regulations and law enforcement practices in other countries should also be elaborated. ${ }^{25}$

Although the rights of victims have been regulated in such a way, in fact, various kinds of problems are often found in the law enforcement process. The first problem is in the process of examining victim reports. With the limitations of law enforcement in interviewing the victim, law enforcement often demeans and inflames the victim's anger. Victims are often asked whether the victim enjoys intercourse and is confronted by the perpetrator. Law enforcement is also considered less professional in terms of collecting evidence. In the process of collecting evidence, victims are often forced to spend millions of rupiah to get a visa. This treatment makes the victim more traumatized and chooses to be reluctant to report the case of sexual violence he experienced. Based on this, reports are low and the number of handling cases of sexual violence decreases. The danger is that the perpetrators as sexual predators are still free to roam. In this case, it is better for the victim to be interviewed in a safe and comfortable room to provide information. The victim can also submit information so that she does not have to be traumatized by giving her testimony many times. This recording is of course an attempt to disguise the identity of the victim, such as a face or voice. ${ }^{26}$

24 Laurensius Arliman, "Reformasi Penegakan Hukum Kekerasan Seksual Terhadap Anak Sebagai Bentuk Perlindungan Anak Berkelanjutan”, Kanun Jurnal Ilmu Hukum, Volume 19, Issue 2, 2017, pp. 307-308.

25 Khoiruddin Nasution, "Kekerasan Seksual dan Perlindungan Anak", Al-Risalah, Volume 1, Issue 16, 2016, p. 21.

26 Ibid, pp. 307-308. 


\section{CASES OF SEXUAL VIOLENCE IN CHILDREN IN THE PERSPECTIVE OF VICTIMOLOGY}

By nature, humans do have a tendency to make various small and big mistakes. So we need rules that can minimize the possibility that mistakes can be repeated. The rules are indeed necessary because humans in their daily lives always intersect and interact with other people. Crime is a form of reality in life that requires special handling. This is because crime will cause unrest in people's lives in general. Therefore, every effort is needed to overcome these crimes, even though in reality it is very difficult to eradicate crime completely. Because basically crime will always develop along with the development of society. ${ }^{27}$ Cases of sexual violence against children certainly have adverse effects on children such as depression, post-traumatic stress disorder, anxiety, tendency to become victims further in adulthood, and physical injury to children among other problems. Judging from legal victimology, it will be clear that the rights of children here are victims of immorality. Based on Law Number 23 of 2002 concerning Child Protection in Article 1 paragraph (2) it is explained that: "Child protection is all activities to guarantee and protect children and their rights so that they can live, grow, develop, and participate optimally in accordance with human dignity and protection, and receive protection from violence and discrimination".

The victimization study is a study that studies victims, the causes of victims and the consequences of victims which are human problems as a form of social reality. Victimology comes from the Latin word victim which means victim and logos which means knowledge. Victimology is a science or study that studies human problems which are a social reality. This formulation results in the need for an understanding, namely:

1. As a form of human problems in proportion to the actual dimensional

2. As a result of interaction due to an interrelation between existing phenomena and mutual influence

3. As the action of a person (individual) who is influenced by elements of a certain social structure in a certain society. ${ }^{28}$

Victimology as a science or study has progressed to the present state which of course does not happen by itself, but has undergone various developments consisting of 3 phases, namely:

1. Victimology only studies victims

2. Victimology does not only study the problem of crime victims

27 Ario Ponco Wiguno, Op. Cit., p. 3.

28 Arif Gosita, "Masalah Korban Kejahatan”, Jakarta: Akademika Pressindo, 1993, p. 40 . 


\section{Raden Muhammad Arvy Ilyasa}

3. Victimology has developed more broadly, namely examining the problems of victims due to abuse of power and human rights. ${ }^{29}$

Children as victims of sexual violence are part of a crime. In addition, the victim also has a role in the occurrence of a crime. The regulation of the protection of victims in the sentencing process in Indonesia shows that the regulation of criminal law against victims of crime has not shown a very clear pattern. Since the advent of modern criminal law, the existence of crime victims seems to have been neglected and therefore their rights are no longer protected. The attention to victims of crime has encouraged a new discipline, namely victimology, which focuses on scientific studies of victims of crime. According to a Dignan, there are 6 (six) factors that influence the birth of victimology and public attention to victims of crime:

1. Contribution of thoughts from Margery Fry, a punitive reform thinker in the 1940s, that the interests of crime victims should be considered

2. Mass media that publicize the suffering of crime victims

3. Increased recognition of the existence of vulnerable groups, in the 1960s

4. There are cases of international and domestic interest that show the suffering of victims

5. Increased knowledge of crime victims through victim surveys

6. Confessions of criminologists. ${ }^{30}$

In the case of sexual violence against children, the science or study of victimology in this case examines the parties to topics about victims, such as the role of the victim in the occurrence of a crime or crime, the relationship between the perpetrator and the victim, the vulnerable position of the victim and the role of the victim in the criminal justice system. According to a Muladi, the scope of victimology includes how someone can become a victim of a victimity that is not always related to crime issues, including patterns of victims of accidents and natural disasters apart from victims of crime and abuse of power. Victimology provides a better understanding of victims of crime as a result of human actions arising from mental, physical, and social suffering. The aim is to be able to provide an explanation of the real issue of the victims and their relationship with the victims as well as to provide confidence and awareness that everyone has the right to know the dangers faced in relation to their environment, work, profession and others. ${ }^{31}$

The first aspect of the topic of victimology that will be discussed by the author in cases of sexual violence against children is about the role

29 Ibid, p. 200.

30 Yeti Kurniati, "Keadilan Restoratif Dalam Perspektif Viktimologi”, Prosiding Seminar Nasional Viktimologi, 2019, p. 283.

31 Muladi, "Hak Asasi Manusia: Hakekat, Konsep dan Implikasinya Dalam Perspektif Hukum Masyarakat", Bandung: Refika Aditama, 2005, p. 109 
of the victim in the occurrence of a crime or crime. Victims can have a role in the occurrence of a crime, either consciously, directly or indirectly. The role referred to here is the attitude and condition of a person who will become a potential victim or attitudes and circumstances that can trigger someone to do evil deeds. Problems then arise regarding the idea of why victims who in fact suffer losses physically, mentally, or in the social aspect, are actually considered to have a role that can trigger a crime, even the victim is sometimes required to take responsibility for actions that are even committed by the perpetrator of crime. ${ }^{32}$ The victim can play a role in a conscious or indirect state, alone or jointly responsible or not, actively or passively, with positive or negative motivation. It all depends on the situation and conditions at the time the incident took place. ${ }^{33}$

The victim in certain situations and conditions can also invite the perpetrator to be able to commit a crime against him as a result of his attitude and actions. Like the victim is negligent in guarding his property so as to provide an opportunity for others to take it without permission. It can also be because the victim is in a vulnerable area or is on duty in the security sector. The victim allows himself to be the target of the crime itself. ${ }^{34}$ Von Hentig believes that the role of the victim in causing a crime is:

1. The crime was really wanted by the victim to happen

2. Losses as a result of crime may be used by the victim to be able to get a bigger profit

3. The result that harms the victim may be a collaboration between the perpetrator and the victim

4. Losses as a result of a crime actually do not occur if there is no provocation from the victim. ${ }^{35}$

The second aspect concerns the relationship between the perpetrator and the victim. In the case of sexual violence against children as a victim, it is a relationship or interaction between a child and an older person or person who is more mature such as a foreigner, sibling or parent where the child is used as an object of sexuality. These acts are carried out using coercion, threats, bribes, deception or pressure. The relationship between the perpetrator and the victim further adds to the complexity of handling cases of sexual crimes against children. Various forms of special support are needed to be able to help children who are victims of sexual violence. ${ }^{36}$

32 Rena Yulia, "Viktimologi: Perlindungan Hukum Terhadap Korban Kejahatan”, Yogyakarta: Graha Ilmu, 2010, p. 75.

Ibid, p. 76.

Ibid, p. 77.

Ibid., p. 81

36 Trini Handayani, "Perlindungan dan Penegakan Hukum Terhadap Kasus Kekerasan Seksual Pada Anak”, Jurnal Mimbar Justitia, Volume 2, Issue 2, 2016, p. 828. 
Raden Muhammad Arvy Ilyasa

The third topic discussed by the author is the role of victims in the criminal justice system. In the context of the criminal justice system, victims of crime need to have their arguments protected, namely:

1. The sentencing process is related to the determination of the criminal through penitensiers (judges, correctional officers, etc. This explains that there are moral demands, in the form of philosophical linkages on the one hand and sociological linkages in the framework of relationships between humans in society on the other hand .

2. Other arguments that put forward legal protection for crime victims are the social contract argument and the social solidarity argument. The state in this case is said to monopolize all social reactions to crime and prohibit private actions, therefore if a crime occurs and brings victims, the state must be responsible for paying attention to the needs of the victims.

3. The protection of victims of crime is usually associated with one of the goals of punishment that is currently being put forward, namely conflict resolution. Conflict resolution here is caused by a crime, restores balance and brings a sense of peace in society. ${ }^{37}$

So far, the regulation of victim protection, especially in the criminal justice system in Indonesia, has not shown a clear pattern. In positive criminal law currently in effect, the protection of victims is more of an indirect protection. This means that the various formulations of criminal acts in the current statutory regulations, in essence, have direct protection of the legal interests and human rights of victims. ${ }^{38}$

\section{CONCLUSION}

Cases of sexual violence against children that occur in Indonesia are very worrying. Protection of children is something that absolutely must be carried out by the State, because the State in the constitution states as a legal state that upholds human rights. Child protection as one of the guarantees of human rights is a tangible manifestation of the development of the regeneration of a country. In the case of child sexual violence, there are factors that trigger, namely personality, environment, relationship between victim and perpetrator, education, moral crisis in society, technological advances, and mass media. In arranging protection for cases of sexual violence against children, seriousness is needed, because when children have experienced this, of course their future will be destroyed, because there is psychological and mental trauma. In

37 Muladi, "Hak Asasi Manusia, Politik, dan Sistem Peradilan Pidana”, Semarang: Badan Penerbit Universitas Diponegoro, 2002, pp. 176-177.

38 Barda Nawawi Arief, "Perlindungan Korban Kejahatan Dalam Proses Peradilan Pidana”, Jurnal Hukum Pidana dan Kriminologi, Volume 1, Issue 1, 1998, pp. 17 18. 
organizing the protection of children from the threat of sexual violence, a law enforcement reform is needed which in the science of victimology is more oriented to the victim, namely the child. So that this country can continue to create the next generation that can be relied on and of course can ensure the sustainability of this country. The advice that can be given by the author is that there should be efforts to prevent and handle sexual crimes against children by synergizing between families, communities and the state. Then on law enforcement in Indonesia that should see the interests of the victims who are not balanced with the interests of the perpetrators of criminal acts in the order of the criminal justice system in the Criminal Procedure Code. Therefore, a change is needed to suit the interests of the victim and aspects of the victimization study to be accommodated in the principle of regulation. This is so that there will be no more violations of the rights of victims and provide guarantees so that the rights of victims are maintained, so that a balance of legal protection can be created for the perpetrators of the crime and the victims.

\section{REFERENCES}

Arief, B. N. (1998). Perlindungan Korban Kejahatan Dalam Proses Peradilan Pidana. Jurnal Hukum Pidana dan Kriminologi, 1(1), 1718.

Arliman, L. (2017). Reformasi Penegakan Hukum Kekerasan Seksual Terhadap Anak Sebagai Bentuk Perlindungan Anak Berkelanjutan, Kanun Jurnal Ilmu Hukum, 19(2), 307-308.

Gosita, A. (1993). Masalah Korban Kejahatan. Jakarta: Akademika Pressindo.

Handayani, T. (2016). Perlindungan dan Penegakan Hukum Terhadap Kasus Kekerasan Seksual Pada Anak, Jurnal Mimbar Justitia, 2 (2.

Hawari, D. (2011). Psikopatologi Kejahatan Seksual. Depok: Badan Penerbit Fakultas Kedokteran Universitas Indonesia.

Kartono, K. (1994). Psychologi Wanita, gadis remaja, dan Wanita Dewasa. Bandung: Alumni.

Komisi Perlindungan Anak Indonesia. (2014). Pedoman Pembentukan Komisi Perlindungan Anak Daerah (KPAD). Jakarta: KPAI.

Kontras. (2013). Keadilan Macet, Kekerasan Jalan Terus: Laporan Tahunan Kondisi HAM di Indonesia. Jakarta: Kontras.

Kurniati, Y. (2019). Keadilan Restoratif Dalam Perspektif Viktimologi, Prosiding Seminar Nasional Viktimologi, 293-300.

Marzuki, P. M. (2005). Penelitian Hukum, Jakarta: Media Group.

Molyneux, E. M., Kennedy, N., Dano, A., \& Mulambia, Y. (2013). Sexual abuse of children in low-income settings: time for action. Paediatrics and international child health, 33(4), 239-246. 
Muladi, M. (2002). Hak Asasi Manusia, Politik, dan Sistem Peradilan Pidana. Semarang: Badan Penerbit Universitas Diponegoro.

Muladi, M. (2005). Hak Asasi Manusia: Hakekat, Konsep dan Implikasinya Dalam Perspektif Hukum Masyarakat. Bandung: Refika Aditama

Nainggolan, L. H. (2008). Bentuk-bentuk kekerasan seksual terhadap anak di bawah umur. Jurnal Equality, 13(1), 73-81.

Nasution, K. (2018). Kekerasan Seksual dan Perlindungan Anak. AlRisalah, 16(1), 19-31.

Pardede, M. (2017). Aspek Hukum kebijakan Penyuluhan Hukum Dalam Rangka Pelaksanaan Sistem Peradilan Pidana Anak. De Jure, 17(1).

Pramukti, A. S., \& Primaharsya, F. (2015). Sistem Peradilan Pidana Anak. Yogyakarta: Pustaka Yusitisia.

Rohmah, N., Rifanda, N., Novitasari, K., \& Nuqul, F. L. (2015). Kekerasan Seksual Padaanak: Telaah Relasi Pelaku Korban Dan Kerentanan Pada Anak. Psikoislamika: Jurnal Psikologi Dan Psikologi Islam, 12(2), 5-10.

Saherodji, H. (1980). Pokok-Pokok Kriminologi. Jakarta: Aksara Baru.

Sardi, M. (2016). Membangun Budaya Hak-Hak Asasi Manusia. Jurnal Media Hukum, 23(1).

Sumiarni, E., \& Halim, C. (2009) Perlindungan Hukum Terhadap Anak Dalam Hukum Keluarga. Yogyakarta: Universitas Atma Jaya.

Sutherland, E. H., \& Cressey, D. R. (1977). Azas-Azas Kriminologi: Principle of Criminology. Bandung: Alumni.

Waluyo, B. (2012). Viktimologi Perlindungan Korban dan Saksi. Jakarta: Sinar Grafika.

Wiguno, A. P. (2013). Kajian Viktimologi Terhadap Anak Sebagai Korban Tindak Pidana Kesusilaan, Jurnal Ilmu Hukum Legal Opinion, 1(1).

Winarta, I. G. A. B. (2005). Hak Asasi (Anak) dalam Realitas Quo Vadis? dalam kumpulan naskah Hak Asasi Manusia (hakekat, Konsep dan Implikasinya dalam perspektif Hukum dan Masyarakat), in Muladi (ed). Bandung: Refika Aditama.

Yanto, O. (2016). Prostitusi Online sebagai Kejahatan Kemanusiaan terhadap Anak: Telaah Hukum Islam dan Hukum Positif. AHKAM: Jurnal Ilmu Syariah, 16(2), 187-196.

\section{Legal Documents}

Kitab Undang-Undang Hukum Perdata

Kitab Undang-Undang Hukum Pidana

Undang-Undang Nomor 39 Tahun 1999 Tentang Hak Asasi Manusia

Undang-Undang Nomor 13 Tahun 2006 Tentang Perlindungan Saksi dan Korban

Undang-Undang Nomor 11 Tahun 2011 Tentang Sistem Peradilan Anak 
Undang-Undang Nomor 35 Tahun 2014 Tentang Perlindungan Anak

\section{Online Sources}

Alfons, M. (2019). "LPSK: Kasus Kekerasan Seksual pada Anak Meningkat Tiap Tahun”, https://news.detik.com/berita/d4637744/lpsk-kasus-kekerasan-seksual-pada-anak-meningkattiap-tahun, accessed on 24 June 2020.

Moerti, W. (2020). "Data KPAI, Selama 2019 Ada 123 Anak Korban Kekerasan Seksual di Institusi Pendidikan", https://www.merdeka.com/peristiwa/data-kpai-selama-2019-ada123-anak-korban-kekerasan-seksual-di-institusipendidikan.html\#: :text=Kontak\%20Kebijakan\%20Privasi,Data\%20KPAI\%2C\%20Selama\%202019\%20Ada\%20123\%20A nak,Kekerasan\%20Seksual\%20di\%20Institusi\%20Pendidikan\&te $\mathrm{xt}=$ Merdeka.com\%20\%2D\%20Komisi\%20Perlindungan\%20Ana k,yang\%20terjadi\%20di\%20institusi\%20pendidikan., accessed on 24 June 2020. 


\title{
Always the innocent are the first victims, so it has been for ages past, so it is now.
}

\author{
J.K. Rowling \\ Harry Potter and the Sorcerer's Stone
}

\section{Conflicting Interest Statement}

All authors declared that there is no potential conflict of interest on publishing this article.

\section{Funding}

None

\section{Publishing Ethical and Originality Statement}

All authors declared that this work is original and has never been published in any form and in any media, nor is it under consideration for publication in any journal, and all sources cited in this work refer to the basic standards of scientific citation.

Cite this article as:

Ilyasa, R. M. A. (2021). Legal and Victimological Perspective on in Sexual Violence against Children Cases in Indonesia. The Indonesian Journal of International Clinical Legal Education, 3(3), 281-300. https://doi.org/10.15294/ijicle.v3i3.48269 